\title{
Location of the primary lacuna in the postembryonic development of selected Cyclophyllidea (Cestoda): a review
}

\author{
N.A. Pospekhova
}

Institute of Biological Problems of the North, Far Eastern Branch of Russian Academy of Sciences, Magadan685000,Russia.E-mail:posna@ibpn.ru

ABSTRACT: The postembryonic development of most cyclophyllids within the intermediate host includes one invagination. This positions the remnants of the primary lacuna between the walls of the dense cyst. Some diplocysts, floricerci and ascocerci undergo two invaginations. In fully formed larvocysts belonging to these types, the remnants of the primary cavity are located between the walls of the additional outer envelope (exocyst). The presence or absence of a primary lacuna is the key characteristic used for metacestode classification. Nonetheless, the position of the primary lacuna during post-embryogenesis may also be important for understanding the evolution of the cestode lifecycle and phylogenetic relations among cyclophyllids.

How to cite this article: Pospekhova N.A. 2017. Location of the primary lacuna in the postembryonic development of selected Cyclophyllidea (Cestoda): a review // Invert. Zool. Vol.14. No.2. P.167-173. doi: 10.15298/invertzool.14.2.11

KEY WORDS: metacestode, cysticercoid, diplocyst, ascocercus, primary lacuna.

\section{Локализация первичной полости в постэмбриональном развитии некоторых циклофиллидей (Cestoda): обзор литературы}

\section{Н.А. Поспехова}

Институт биологических проблем Севера ДВО РАН, Магадан 685000, Россия. E-mail: posna@ibpn.ru

РЕЗЮМЕ: Постэмбриональное развитие в промежуточном хозяине у большинства циклофиллидей включает одну инвагинацию. В результате остатки первичной полости размещаются между стенками плотной цисты. Некоторые диплоцисты, флорицерки и аскоцерки претерпевают две инвагинации. В полностью сформированных лярвоцистах, принадлежащих к этим типам, остатки первичной полости расположены между стенками дополнительной внешней оболочки (экзоцисты). Наличие или отсутствие первичной полости является важным признаком для классификации метацестод, однако локализация первичной полости во время постэмбриогенеза также может быть важным обстоятельством для понимания эволюции жизненных циклов цестод и возможных филогенетических связей в пределах циклофиллидей. Как цитировать эту статью: Pospekhova N.A. 2017. Location of the primary lacuna in the postembryonic development of selected Cyclophyllidea (Cestoda): a review // Invert. Zool. Vol.14. No.2. P.167-173. doi: 10.15298/invertzool.14.2.11

КЛЮЧЕВЫЕ СЛОВА: метацестода, цистицеркоид, диплоциста, аскоцерк, первичная полость. 
A.

Cercocysticercoid
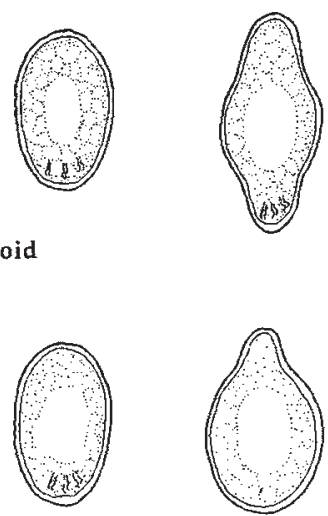

C Diplocysticercoid

E Monocysticercoid
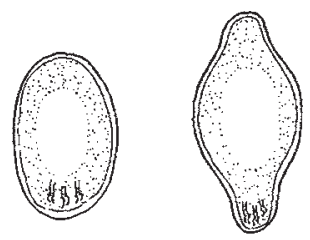

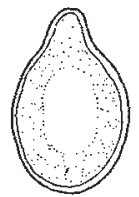

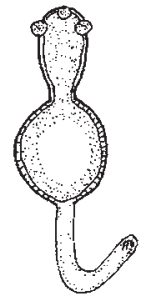
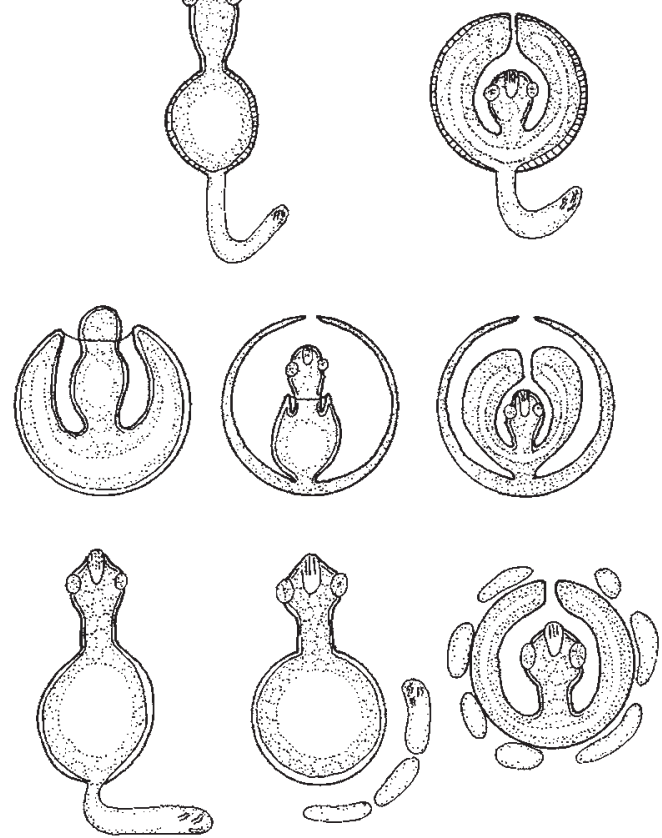

Fig. 1. Schematic representation of development of different types of cysticercoids (after Lenta Chervy, 2002; fragment of Fig. 3).

Рис. 1. Схематическое изображение развития различных типов цистицеркоидов (по: Lenta Chervy, 2002; часть рис. 3).

The presence or absence of the primary lacuna stage in postembryonic development is the key character to define various types of metacestodes (Freeman, 1973, Lenta Chervy, 2002). Cysticercoids, the main type of cyclophyllid metacestodes, have a primary lacuna, but its position during the formation of the invasive larvocyst is not the same across species (Voge, 1967; Freeman, 1973; Gulyaev, 1977). The reason for the displacement of the primary lacuna from the dense cyst to an additional outer envelope has not been studied. The fact that such a displacement takes place may be important for a more precise definition of the term 'cercomer', which is widely used in describing and classifying metacestodes (Freeman, 1973; Jarecka, 1975; Krasnoshchekov, 1980; Jarecka et al., 1981; Lenta Chervy, 2002).

Moreover, the position of the primary lacuna in ontogeny may be connected with the peculiarities of the biology of these species and should therefore be taken into account when analyzing the adaptive strategies of cestodes during the developmental period in the intermediate host. This approach may be useful in analyzing the evolution of the cestode lifecycle and in determining phylogenetic relationships within the order Cyclophyllidea. Our review is designed to draw the attention of morphologists and cestodologists to the heterogeneity of the processes of cyclophyllid metacestode formation in the early stages of post-embryogenesis.

The post-embryonic development of most studied cyclophyllids follows a general scheme and includes (according to various authors) the following basic stages: migrating oncosphere, metamorphosis, megalosphere or the formation of the primary lacuna ('lacuna primitiva'), elongation, metamere or the separation of the anlage into anterior and posterior poles (the latter represents a future tail appendage, or cercomer, according to other authors), scolexogenesis, 


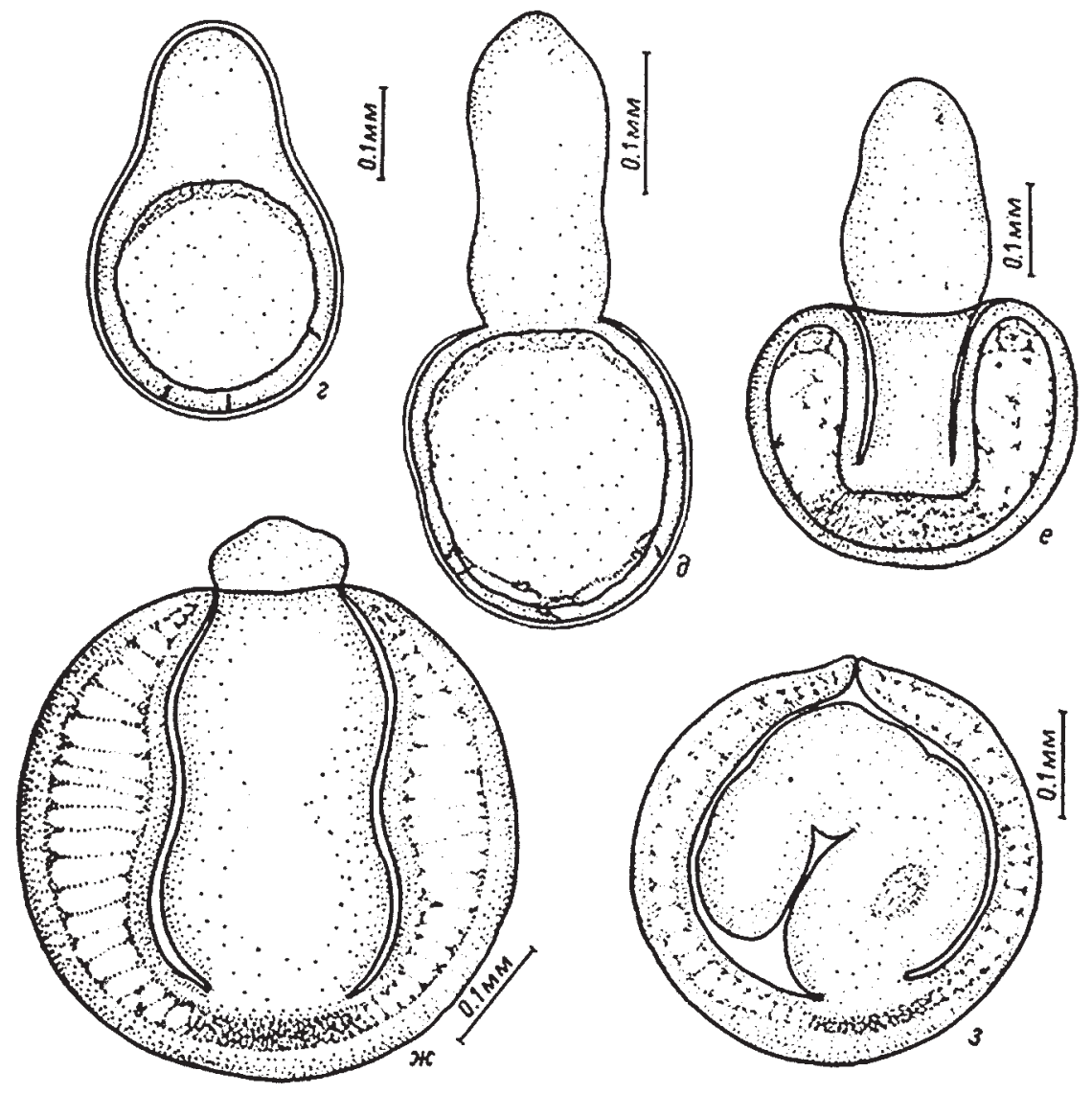

Fig. 2. Stages of larvogenesis in Aploparaksis furcigera (Rud., 1819) Fuhrmann, 1926 (after Gulyaev, 1977; fragment of Fig.1).

Рис. 2. Стадии лярвогенеза Aploparaksis furcigera (Rud., 1819) Fuhrmann, 1926 (по: Гуляев, 1977; часть рис. 1).

invagination (immersion of the metacestode's definitive part into the cyst cavity) and a completely developed cysticercoid (larvocyst) (Skrjabin, Mathevossian, 1945; Freeman, 1973; Krasnoshchekov, Tomilovskaya, 1978; Bondarenko, Kontrimavichus, 2006).

According to this developmental scheme, the primary lacuna (more specifically its remnants) is located between the outer and inner walls of the dense cyst. For convenience, we denote this larvocyst formation method as the basic one. It is typical of cercocysts, monocerci, microcerci and some diplocysts (Fig. 1A-E).

A more complex postembryonic development process, including two invaginations and an additional outer envelope (exocyst) formation, is characteristic of several types of metacestodes: some diplocysts, floricerci and various ascocerci (Bondarenko \& Kontrimavichus, 2006; Nikishin, 2010; Regel et al., 2013).

Detailed descriptions of typical diplocyst larvogeny were provided by Gulyaev (1977) and Bondarenko (1989). The authors found that, during the first invagination, the cystoscolex anlage immerses into the forming exocyst, while the remainder of the primary lacuna is located between its walls. The further differentiation of the cystoscolex anlage includes the de novo formation of an invagination cavity in the future endocyst(Fig. 2). Thus, the second invagination 

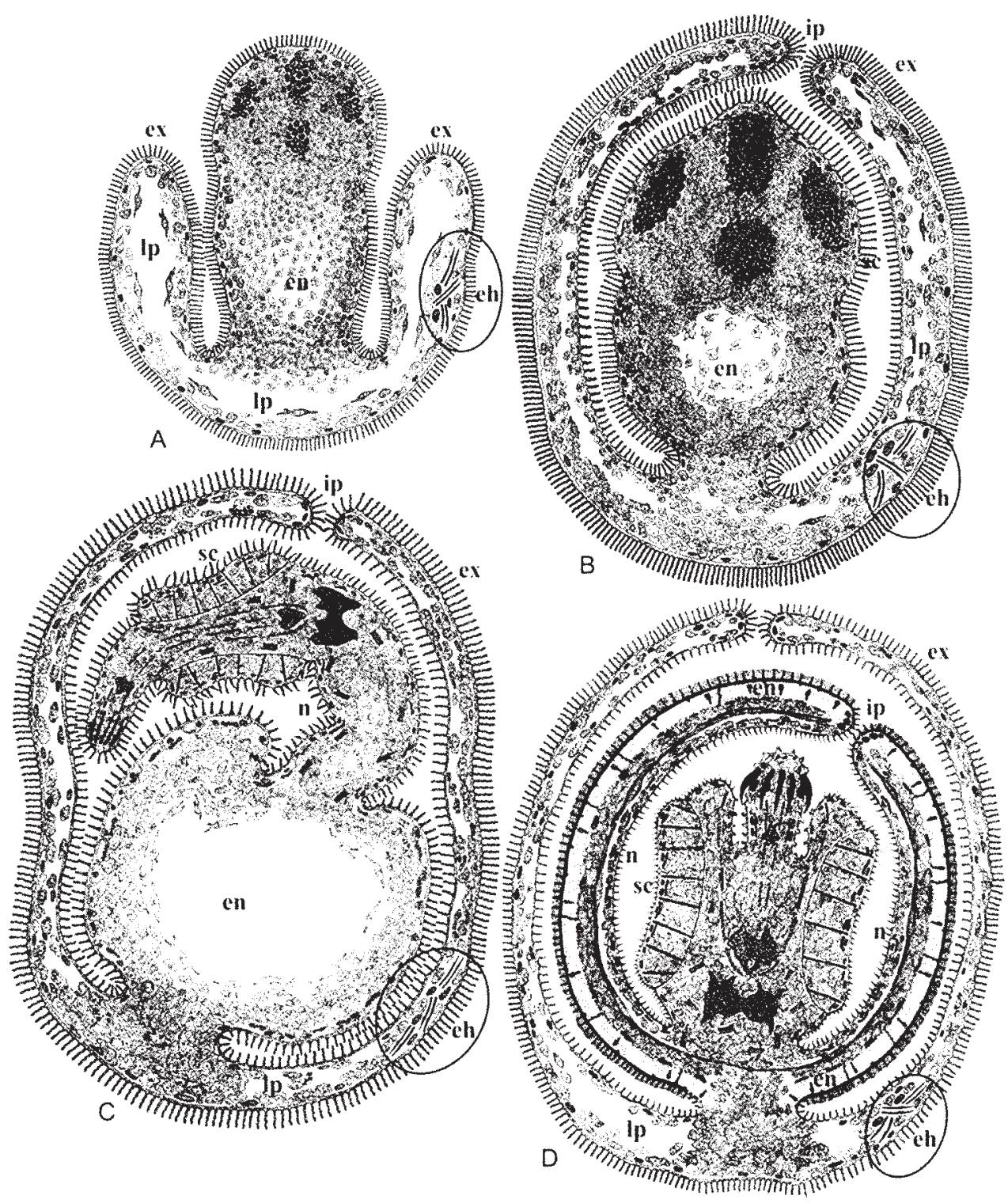

Fig. 3. Schematic representation of Aploparaksis bulbocyrrus Deblock et Rausch, 1968 at different stages of development. A - beginning of first invagination; B - completion of first invagination and beginning of scolexogenesis; C — late scolexogenesis; D - cysticercoid (after Nikishin, 2010)

Рис. 3. Схемы организации типичной диплоцисты Aploparaksis bulbocyrrus Deblock et Rausch, 1968 на разных стадиях её развития. А - начало первой инвагинации; Б - завершение первой инвагинации и начало сколексогенеза; C - поздний сколексогенез; D — цистицеркоид (по: Nikishin, 2010).

in a typical diplocyst is identical to that occurring under the basic larvocyst-formation method. In both cases, the definitive part of the metacestode becomes submerged into the cavity of the cyst. Electron microscopic examinations of typical diplocysts at various stages of formation have confirmed the conclusions of Gulyaev (1977) and Bondarenko (1989) and have yielded new 

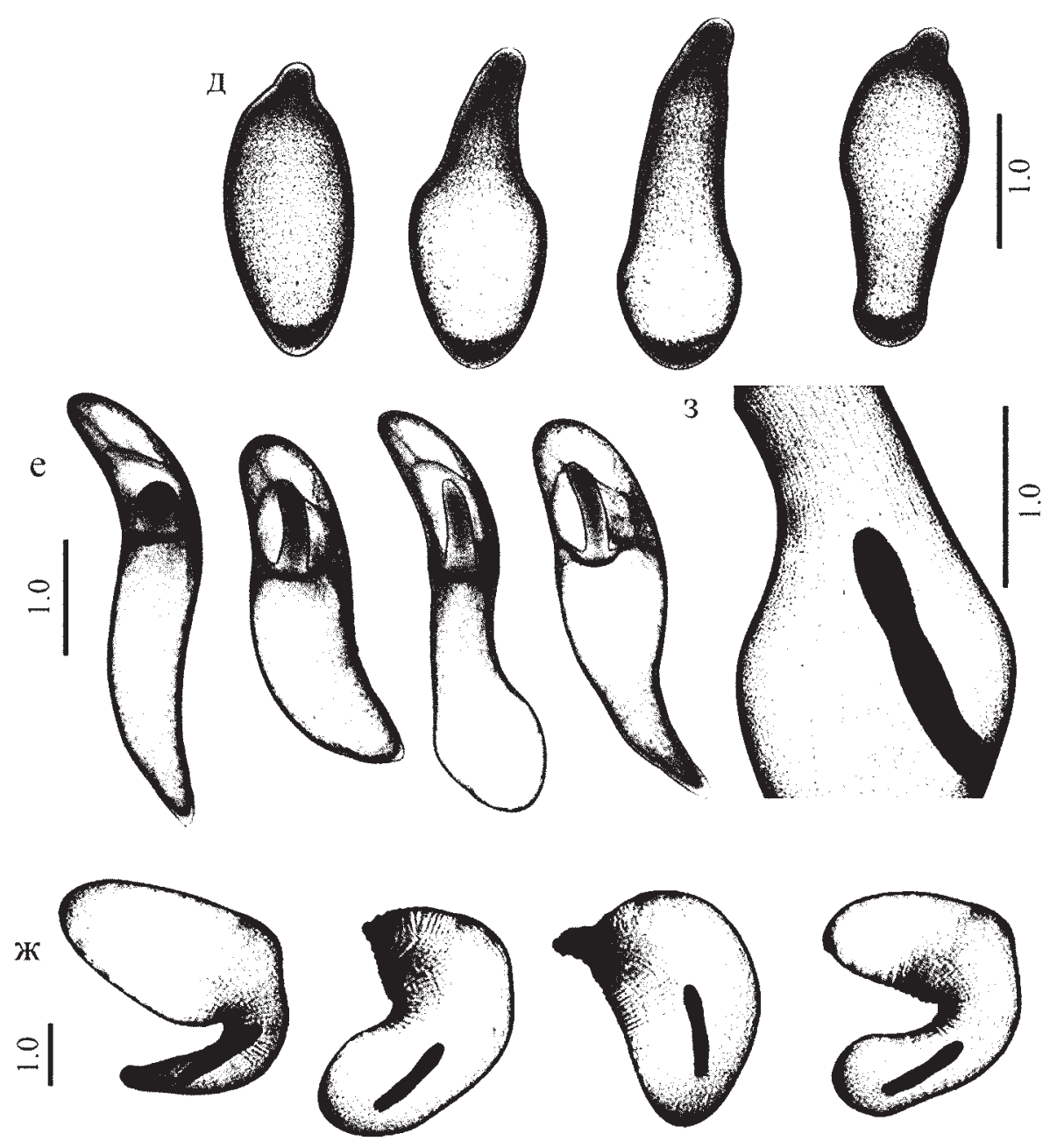

Fig. 4. Early developmental stages of Dioecocestus asper (Mehlis, 1831) megalocercus. D - elongation and exogenous formation of cystoscolex anlage; $\mathrm{E}$ - first invagination; Ж, 3 - growth and beginning of cystoscolex anlage differentiation (after Regel et al., 2013).

Рис. 4. Ранние стадии развития мегалоцерка Dioecocestus asper (Mehlis, 1831). D — фаза удлинения и экзогенного формирования зачатка цистосколекса; Е - первая инвагинация; Ж, 3 - рост и начало дифференциации зачатка цистосколекса (по: Regel et al., 2013).

data regarding the cellular composition of this cysticercoid (Nikishin, 2010) (Fig. 3).

The analysis of the literature data shows that the displacement of the primary lacuna to the outer envelope is not a stable character, even within the family. Thus, within the family Aploparaksidae, several types of metacestodes which differ in the structure of the outer envelope as well as in the process of their formation and the destiny of their primary lacunae are described (Bondarenko, Kontrimavichus, 1976). In addition to typical diplocysts, the primary lacuna has a similar developmental result in the egg-like diplocyst, as well as in the floricercus (Bondarenko, Kontrimavichus, 2006).

According to Gulyaev (1977), the formation of an additional outer envelope in a typical diplocyst is an adaptation to parasitism in strong- 
ly muscular intermediate hosts (oligochaetes); the derivate of the primary lacuna is filled with rigid cells, providing exocyst resistance.

Note, however, that ascocercus, which has a similar formation method, develops in dragonfly larvae with a hard chitinous exoskeleton (Rees, 1973; Gulyaev et al., 2010). The biology and morphology of various ascocerci have shown that, in the real ascocercus and megalocercus, the primary lacuna is shifted to the outer cellular envelope (Fig. 4), and the invagination cavity in the forming dense cyst (endocyst) arises de novo (Regel et al., 2013; Regel, Pospekhova, 2014). Thus, the position of the primary lacuna and the process of ascocercus formation are similar to the process of typical diplocyst formation.

Perhaps the appearance of an outer envelope in ascocerci ontogenesis is due to other causes. For instance, ascocercus needs to reduce the amount of antigens entering the abdominal cavity of the host and, at the same time, provide the definitive part of the metacestode with nutrients. This conclusion is in accordance with the morphological and ultrastructural features of ascocercus: a fully developed ascocercus has a closed exocyst into which the excretory atrium of the endocyst opens, and the tegument of the exocyst wall has all the features of active transport, particularly a huge number of mitochondria in the cytons and the distal cytoplasm (Pospekhova et al., 2014; Pospekhova, Regel, 2015).

Cyclophyllid metacestodes were repeatedly classified by type (Skrjabin, Mathevossian, 1945; Voge, 1967; Freeman, 1973; Jarecka, 1975; Bondarenko, Kontrimavichus, 1976; Krasnoshchekov, 1980; Gulyaev, 1997; Lenta Chervy, 2002). The latter work, which summarizes previous classification systems, attaches great importance to the presence or absence of the primary lacuna, and the presence of a cercomer (called a tail appendage by other authors) is considered to be a useful secondary characteristic. The same authors note a wide variety of cysticercoids and deficiencies in the available knowledge on specific types of larval cestodes. All morphologically studied cysticercoids have a primary lacuna, but its developmental out- come is realized in two variants. Either the remnants of the primary lacuna lie between the walls of a dense cyst (cercocysts, monocerci and some diplocysts), as in most cases, or they are located between the walls of the outer envelope (exocysts), and the invagination cavity arises de novo in the forming dense cyst (some diplocysts, floricerci and ascocerci) (Voge, 1967; Freeman, 1973; Gulyaev, 1977; Krasnoshchekov, Tomilovskaya, 1978; Bondarenko, 1989; Nikishin, 2010; Regel, Pospekhova, 2014). These data indicate the heterogeneity of the early stages of cysticercoid formation, particularly primary lacuna position.

The position of the primary lacuna in various envelopes of cysticercoids may be an additional argument in favor of defining the cercomer as the entire complex of auxiliary structures (all envelopes, bladders and tail appendages) providing development within the intermediate host (Jarecka, 1975; Krasnoshchekov, 1980; Jarecka et al., 1981), not merely as a tail appendage (Freeman, 1973; Gulyaev, 1997; Lenta Chervy, 2002). The term 'cercomer' can be understood as a synonym of 'caenogenesis' after Severtsov (1939), who used this term to refer to provisional structures.

\section{References}

Bondarenko S.K. 1989. [Aplaparaksis australis Johnston, 1911 and its life cycle] // Acta Parasitologica Lithuanica. Vol.23. P.99-114 [in Russian].

Bondarenko S.K., Kontrimavichus V.L. 1976. Polymorphism of larvae of the genus Aploparaksis Clerc, 1903 (Hymenolepididae) // Folia Parasitologica. Vol.23. P.39-44.

Bondarenko S.K., Kontrimavichus V.L. 2006. [Aplaparaksidae of wild and domesticated birds] // Fundamental of Cestodology. T.14. Moscow: Nauka. 443 p. [in Russian]

Freeman R.S. 1973. Ontogeny of cestodes and its bearing on their phylogeny and systematics // Advances in Parasitology. Vol.11. P.481-557.

Gulyaev V.D. 1977. Larvogenesis of diplocyst of Aploparaksis furcigera (Rud., 1819) Fuhrmann, 1926 (Cestoda, Hymenolepididae) // Parazitologiya. T.11. P.1722 [in Russian].

Gulyaev V.D. 1997. [Classification of metacestodes as a system of life-forms characteristic to cestode parasitic larvae] // Byulleten Moskovskogo Obshchestva Ispyiatelei Prirodi. Otdel biol. Vol.102. P.26-33 [in Russian]. 
Gulyaev V.D., Regel K.V., Pospekhova N.A., Atrashkevich G.I. 2010. [The role of dragonflies in the life cycles of Schistotaeniidae and Dioecocestidae in NorthEast Asia] // Parasites of the Holarctic Region: Proceedings of International symposium. Petrozavodsk, 2010. Vol.1. P.84-86 [in Russian].

Jarecka L. 1975. Ontogeny and evolution of cestodes // Acta Parasitologica Polonica. Vol.23. P.93-114.

Jarecka L., Michajlow W., Burt, M.D.B. 1981. Comparative ultrastructure of cestode larvae and Janicki's cercomer theory // Acta Parasitologica Polonica. Vol.28. P.65-72.

Krasnoshchekov G.P. 1980. [Cercomere - a larval organ of cestodes] // Zhurnal obshchey biologii. Vol.41. P.615-627 [in Russian]

Krasnoshchekov G.P., Tomilovskaya N.S. 1978. [Morphology and development of cysticercoids Paricterotaenia porosa (Rud., 1810) (Cestoda: Dilepididae)] // Parazitologiya. Vol.12. P.108-115 [in Russian]

Lenta Chervy. 2002. The terminology of larval cestodes or metacestodes // Systematic Parasitology. Vol.52. P.133.

Nikishin V.B. 2010. [Structure and differentiation of the tissues of cysticercoids. 3. Differentiation of the endocyst of typical diplocyst of Aploparaksis bulbocirrus (Cestoda: Aploparaksidae)] // Invertebrate Zoology. Vol.7. No.2. P.159-176 [in Russian, with English summary].

Pospekhova N.A., Regel K.V. 2015. Morphology and ultrastructure of two schistotaeniid cysticercoids (Cestoda: Cyclophyllidea) from the haemocoele of the dragonfly larvae // Parazitologiya. Vol.49. P.339351 .

Pospekhova N.A., Regel K.V., Gulyaev V.D. 2014. Ultrastructural study of protective envelopes in Dioecocestus asper (Cestoda: Dioecocestidae) megalocercus // Parazitologiya. Vol.48. P.89-96.

Rees G. 1973. The ultrastructure of the cysticercoid of Tatria octacantha Rees, 1973 (Cyclophyllidea: Amabiliidae) from the haemocoele of the damsel-fly nymphs Pyrrhosoma nymphula Sulz and Ehallagma cyathigerum Charp // Parasitology. Vol.67. P.85-103.

Regel K.V., Gulyaev V.D., Pospekhova N.A. 2013. [On the life cycle and morphology of metacestodes Dioecocestus asper (Cyclophyllidea: Dioecocestidae)] // Parazitologiya. Vol.47. P.3-22. [in Russian]

Regel K.V., Pospekhova N.A. 2014. [On morphogenesis of metacestodes from the family Schistotaeniidae (Cyclophyllidea) by the example of euascocercus Schistotaenia srivastavai Raush, 1970] // Parazitologyia. Vol.48. P.206-219 [in Russian]

Severtsov A.N. 1939. [Morphological patterns of evolution]. Moscow, Leningrad: AN SSSR Publ. 610 p. [in Russian]

Skrjabin K.I., Mathevossian E.M. 1945. Hymenolepidid cestodes of domestic and game birds. Moskow. 488 p. [In Russian]

Voge M. 1967. The post-embryonic developmental stages of cestodes // Advances in Parasitology. Vol.11. P.707730 .

Responsible editor E.N. Temereva 